\title{
BADANIA W KOŚCIELE PW. ŚW. APOSTOLÓW PIOTRA I PAWLA W RĄBINIU, POW. KOŚCIAŃSKI. PRZYCZYNEK DO STUDIÓW NAD SAKRALNĄ ARCHITEKTURĄ ROMAŃSKĄ W POLSCE
}

\author{
RESEARCH CARRIED OUT IN THE CHURCH \\ OF THE HOLY APOSTLES PETER AND PAUL IN RĄBIŃ, KOŚCIAN COUNTY. \\ A CONTRIBUTION TO THE STUDIES INTO SACRAL ROMANESQUE \\ ARCHITECTURE IN POLAND
}

Pamięci prof. dr. hab. Stanisława Kurnatowskiego

\begin{abstract}
In late November and early December 2012, emergency archaeological and architectural research was carried out in the Parish Church of the Holy Apostles in Rąbiń, Kościan county. The relics of a stone Romanesque church were studied thoroughly; it is a clear-span building with a deep apse/ chancel dating back to the first half of the $13^{\text {th }}$ century. The subsequent phases of the church's renovation from the $13^{\text {th }}$ century until today have also been identified.
\end{abstract}

Keywords: Rąbiń, parochial church, Romanesque culture, a clear-span building, aisle, apse, chancel, architectural detail.

Według dotychczasowych ustaleń parafia rąbińska należy do najstarszych w archidiecezji poznańskiej, choć pierwsza o niej wzmianka źródłowa pochodzi dopiero z 1391 roku. Józef Nowacki w swym monumentalnym dziele poświęconym dziejom archidiecezji poznańskiej początki parafii w Rąbiniu odniósł do XII stulecia (Nowacki 1964, s. 424), natomiast budowę kościoła parafialnego do wieku XIII, nie dając przy tym wiary przekazowi Jana Długosza, który jego powstanie wiązał z XII w. i osobą Piotra Włostowica (Nowacki 1964, s. 428). Teresa Ruszczyńska i Aniela Sławska określiły powstanie obiektu na wiek XIII (Ruszczyńska i Sławska 1980, s. 92), Izabela Skierska przy opisie kościoła wspomniała jedynie

\footnotetext{
* Pracownia Archeologiczno-Konserwatorska „mgr Alina Jaszewska” w Zielonej Górze, Oddział w Poznaniu, ul. Woźna nr 12, 61-677 Poznań.
} 